\title{
Effect of Sodium Butyrate, Sodium Salt of Medium Chain Fatty Acids (Dicosan) in Combatting Clostridium perfringens Induced Necrotic Enteritis in Broiler Chicken
}

\author{
Dayaram Suryawanshi*, Sonali Shete, Rutuja Shelke, Mrugali Patil, \\ Hrishikesh Kamat and Pavan Pawar \\ Department of Pathology, Omega Laboratories, India \\ *Corresponding Author: Dayaram Suryawanshi, Department of Pathology, Omega \\ Laboratories, India.
}

Received: November 10, 2021

Published: November 29, 2021

(C) All rights are reserved by Dayaram

Suryawanshi., et al.

\begin{abstract}
Present study was conducted to evaluate the efficacy of sodium butyrate, sodium salts of medium chain fatty acids and their combinations against the induced necrotic enteritis in broiler chickens. The study was undertaken on 480 broiler birds. Birds were distributed in 5 groups viz. Normal control $(\mathrm{NC})$, Negative control $(\mathrm{NC}+\mathrm{C})$, sodium salt of butyrate (SB+C), Medium chain Fatty acids (Dicosan) $(\mathrm{MCFA}+\mathrm{C})$ and SB + MCFA $\left(\right.$ Dicosan $\left.^{+}\right)+C$ groups. Standard management practices and vaccinations were carried out. On day 18 birds were inoculated orally with suspension of Clostridium perfringens, and on day 4, 5 and 6 post infections, one bird was sacrificed from each replicate. The gross pathological score out of 4 was $3.4806,1.882,1.68$ and 0.73 respectively in $\mathrm{NC}, \mathrm{NC}+\mathrm{C}, \mathrm{SB}+\mathrm{C}$ , MCFA+C and SB+MCFA+C, respectively. Microscopic score was 3.2652, 1.378, 1.296 and 0.7318, respectively for groups NC, NC+C, $\mathrm{SB}+\mathrm{C}, \mathrm{MCFA}+\mathrm{C}$ and $\mathrm{SB}+\mathrm{MCFA}+\mathrm{C}$. Fecal culture was carried out before induction of infection, during course of infection and at the end of experiment i.e. on day 42. Group SB + MCFA+ challenge showed better reduction in clostridium count as compared to other treatment groups. Negative control + challenge group showed higher clostridium count as compared to all treatment groups.
\end{abstract}

Keywords: Sodium Salts of Butyrate; Medium Chain Fatty Acids; Clostridium perfringens; Necrotic Enteritis

\section{Abbreviations}

NC: Normal Control; NC+C: Negative Control + Challenge, SB: Sodium Salt of Butyrate, MCFA: Medium Chain Fatty Acids, CFU: Colony Forming Units

\section{Introduction}

Protein requirement for the better immunity in the era of covid pandemic is an essential part of our daily diet [1]. Good quality of chicken meat with appropriate nutritional values is most important aspect. For the better intestinal health of broilers many chemicals, drugs, antibiotics are used routinely [2,3]. These antibiotics will be having some residual effects and that found to be human health issues [4]. To avoid these residual effects ingredients which can have no any residual effects and on the other hand found to be much beneficial to broiler health too is the need of modern broiler farming $[5,6]$. Medium chain fatty acids are saturated and unbranded with 8-12 carbons. These compounds selectively stimulate the favorable growth or activity of beneficial bacterial species and the death of harmful bacteria inhabiting the digestive tract of poultry [7]. Modes of action are Increased cell permeability and thereby causing cell leakage, inhibition of enzymes, inhibition of nutrient uptake and Disruption of the electron transport chain resulting in the less energy for the bacteria.

Sodium butyrate is the sodium salt of butyric acid which contains sodium atom in place of hydrogen of $-\mathrm{OH}$ group. Beneficial health effects of butyrate are well documented, and it has been shown to have positive effects on broiler production parameters such as weight gain, feed intake, and FCR [8].

The efficacy of sodium butyrate depends upon the pKa value of butyric acid and $\mathrm{pH}$ of the corresponding part of the digestive system viz. crop, proventriculus, gizzard and small intestine. $\mathrm{pKa}$ is the $\mathrm{pH}$ value of an acid at which half the molecules of that acid are dissociated into positive and negative ions. Sodium butyrate is 
Effect of Sodium Butyrate, Sodium Salt of Medium Chain Fatty Acids (Dicosan) in Combatting Clostridium perfringens Induced Necrotic Enteritis in Broiler Chicken

converted into butyric acid after ingestion. The bactericidal effects of butyric acid require it to be un-dissociated for entry into the bacterial cell [8].

\section{Materials and Methods}

- $\quad$ Present study was carried out on 480 broiler birds at Omega Laboratories Research facility. One day old broiler chicks were procured from reputed hatchery. Birds were distributed in various groups as stated in table 1, which includes inclusions of test ingredients and table 2 consisted of numbers of birds and replicates. Standard brooding, feeding and watering procedures were carried out from day old till the end of trial.

- Medium chain fatty acids MCFA - Dicosan and combination of sodium salt of butyrate SB and Medium chain fatty acids MCFA Dicosan ${ }^{+}$were received from Neutrient BioAgro Tech Pvt. Ltd (NBPL NOREL SA), Pune for the efficacy trial.

- Induction of infections: Clostridium infection was induced on age, Day 18, with Clostridium perfringens 2.3 $\mathrm{X} 10^{6} / \mathrm{ml}$ as suspension, was given orally. Suspension of bacterium was grown in laboratory, collected from the field cases and incubated in Clostridium perfringens sporulation propagation broth (HiMedia M947) (Table 3).

- From each replicate one bird was sacrificed on day 4, 5 and 6 after giving challenge of Clostridium perfringens infection and detailed examination of organs and intestinal tract was carried out and lesions were evaluated and scores were noted. Normal control group was not considered for the scoring of necrotic enteritis. Histopathology of intestines of these birds were carried by Paraffin embedding technique and microphotography was carried out with the help of Olympus Mega vision camera and microscopic scoring of necrotic enteritis was carried out by modified method [9].

- Fecal culture examination was carried out at the commencement of study, during study and on $42^{\text {nd }}$ day of study. Pooled samples were collected from each replicate with the help of sterile fecal collection spoon. For clostridium detection, Clostridium agars (HiMedia M2070) were used for isolation and identification (Hi- Media laboratory manual).

- No any statistical method and designs has been used for the present study.

\begin{tabular}{|l|c|c|c|}
\hline Groups & $\begin{array}{c}\text { Numbers of } \\
\text { replicates }\end{array}$ & $\begin{array}{c}\text { Numbers of birds } \\
\text { per replicates }\end{array}$ & $\begin{array}{c}\text { Total } \\
\text { birds }\end{array}$ \\
\hline $\begin{array}{l}\text { NC (no additive } \\
\text { supplementation and } \\
\text { no challenge); }\end{array}$ & 12 & 8 & 96 \\
\hline NC + Challenge & 12 & 8 & 96 \\
\hline SB + Challenge & 12 & 8 & 96 \\
\hline MCFA + Challenge & 12 & 8 & 96 \\
\hline SB + MCFA + Challenge & 12 & 8 & 96 \\
\hline
\end{tabular}

Table 1: Replicates and distribution of birds per replicates.

\begin{tabular}{|l|c|c|c|}
\hline Groups & Pre starter & Starter & Finisher \\
\hline $\begin{array}{l}\text { NC (no additive } \\
\text { supplementation and } \\
\text { no challenge); }\end{array}$ & Nil & Nil & Nil \\
\hline NC + Challenge & Nil & Nil & Nil \\
\hline SB + Challenge & $\begin{array}{c}1.5 \mathrm{~kg} / \text { ton of } \\
\text { feed }\end{array}$ & $\begin{array}{c}1 \mathrm{~kg} / \text { ton of } \\
\text { feed }\end{array}$ & $\begin{array}{c}0.5 \mathrm{~kg} / \text { ton of } \\
\text { feed }\end{array}$ \\
\hline $\begin{array}{l}\text { MCFA (Dicosan) + } \\
\text { Challenge }\end{array}$ & $\begin{array}{c}1.5 \mathrm{~kg} / \text { ton of } \\
\text { feed }\end{array}$ & $\begin{array}{c}1 \mathrm{~kg} / \text { ton of } \\
\text { feed }\end{array}$ & $\begin{array}{c}0.5 \mathrm{~kg} / \text { ton of } \\
\text { feed }\end{array}$ \\
\hline $\begin{array}{l}\text { SB + MCFA (Dicosan }+ \\
+ \text { Challenge }\end{array}$ & $\begin{array}{c}1.5 \mathrm{~kg} / \text { ton of } \\
\text { feed both }\end{array}$ & $\begin{array}{c}1 \mathrm{~kg} / \text { ton of } \\
\text { feed of both }\end{array}$ & $\begin{array}{c}0.5 \mathrm{~kg} / \text { ton of } \\
\text { feed of both }\end{array}$ \\
\hline
\end{tabular}

Table 2: Additives used (Dicosan and Dicosan $^{+}$are the products of Norel).

\begin{tabular}{|l|c|c|}
\hline Groups & $\begin{array}{c}\text { Clostridium } \\
\text { perfringens on } \\
\text { day 18 }\end{array}$ & Sacrifice on \\
\hline $\begin{array}{l}\text { NC (no additive } \\
\text { supplementation and } \\
\text { no challenge); }\end{array}$ & Nil & $\begin{array}{c}1 \text { bird from each } \\
\text { group on day } 4,5 \\
\text { and } 6\end{array}$ \\
\hline NC + Challenge & $\begin{array}{c}\text { Yes }\left(2.3 \times 10^{6} / \mathrm{ml} \text { as }\right. \\
\text { suspension) }\end{array}$ & $\begin{array}{c}1 \text { bird from each } \\
\text { group on day } 4,5 \\
\text { and } 6 \text { after } \\
\text { infection }\end{array}$ \\
\hline SB + Challenge & $\begin{array}{c}\text { Yes }\left(2.3 \times 10^{6} / \mathrm{ml} \text { as }\right. \\
\text { suspension) }\end{array}$ & $\begin{array}{c}1 \text { bird from each } \\
\text { group on day } 4,5 \\
\text { and } 6 \text { after } \\
\text { infection }\end{array}$ \\
\hline MCFA + Challenge & $\begin{array}{c}\text { Yes }\left(2.3 \times 10^{6} / \mathrm{ml} \text { as }\right. \\
\text { suspension) }\end{array}$ & $\begin{array}{c}1 \text { bird from each } \\
\text { group on day } 4,5 \\
\text { and } 6 \text { after } \\
\text { infection }\end{array}$ \\
\hline SB + MCFA + Challenge & $\begin{array}{c}\text { Yes }\left(2.3 \times 10^{6} / \mathrm{ml} \text { as }\right. \\
\text { suspension) }\end{array}$ & $\begin{array}{c}1 \text { bird from each } \\
\text { group on day } 4,5 \\
\text { and } 6 \text { after } \\
\text { infection }\end{array}$ \\
\hline
\end{tabular}

Table 3: Challenge. 
Effect of Sodium Butyrate, Sodium Salt of Medium Chain Fatty Acids (Dicosan) in Combatting Clostridium perfringens Induced Necrotic Enteritis in Broiler Chicken

\section{Results and Discussion}

Microbiological investigations were carried out and it was observed that group SB+ MCFA showed better performance and able to combat the all types of infections as compared to all the treated groups.

Gross pathological alterations in the negative control group were higher as compared to other treatment groups and lower gross pathological observations noticed in SB + MCFA + challenge group (Table 4 and graph 1 and plate 1 ). Similar trend was evident in the microscopic observations. Severe histopathological changes were observed in negative control + challenge groups as compared to all other groups. Amongst the all the groups, group SB +MCFA+ challenge showed better recovery and lower pathological scores as compared to other groups. (Table 5 and graph 2 and plate 2). Clostridium perfringens count was reduced in SB + C, MCFA + C and tremendously reduced in group SB + MCFA + challenge group (Table 6). Sodium salt of butyrate and medium chain fatty acids are able to destroy the bacterial cell by dissociation in intestinal mucosal surfaces. Due to unavailability of nutrition for the bacterial cell growth, harmful bacteria like E. coli, salmonella, clostridium get eliminated from the intestinal tract and hence make intestinal tract healthy. Similar findings were quoted by many scientist [6$8,10]$ were evident in the present study.

\begin{tabular}{|l|c|c|c|c|c|c|}
\hline Group & $\begin{array}{c}\text { Bulging of intestinal } \\
\text { segment }\end{array}$ & Haemorrhages & Necrosis & Blood clots & $\begin{array}{c}\text { Pseudo } \\
\text { membrane } \\
\text { formation }\end{array}$ & $\begin{array}{c}\text { Average } \\
\text { score }\end{array}$ \\
\hline Negative Control + Challenge & 3.91 & 3.583 & 3.5 & 3.75 & 2.66 & 3.4806 \\
\hline SB + Challenge & 2.25 & 2.25 & 2 & 1.66 & 1.25 & 1.882 \\
\hline MCFA + Challenge & 1.83 & 1.75 & 1.83 & 1.66 & 1.33 & 1.68 \\
\hline SB+ MCFA + Challenge & 0.91 & 0.91 & 1 & 0.75 & 0.08 & 0.73 \\
\hline
\end{tabular}

Table 4: Average Gross pathology scoring of intestines, out of 4 .

Table 4 indicates gross pathological score: higher pathological score of 3.4806 in group negative control and challenge, 1.882 was pathological score for group SB + challenge, 1.68 was the score for $\mathrm{MCFA}+$ challenge and lowest score of 0.76 was noticed in combination of SB + MCFA. The graphical representation of the same has been given in graph 1 . And group wise gross pathology has been given in plate 1 and in images $A, B, C$ and $D$. This is an indication of better bactericidal effects of SB and MCFA against Clostridium perfringens.

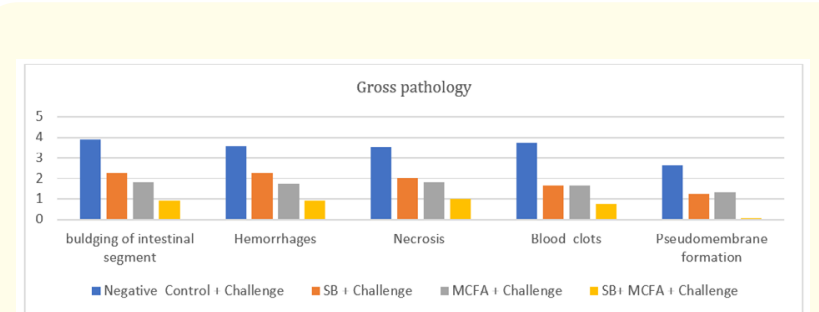

Graph 1: Average Gross pathology scoring of intestines, out of 4 .

\begin{tabular}{|l|c|c|c|c|c|c|}
\hline Group & $\begin{array}{c}\text { Sloughing of } \\
\text { epithelium }\end{array}$ & Necrosis & Haemorrhages & Cellular infiltration & $\begin{array}{c}\text { Pseudo membrane } \\
\text { formation }\end{array}$ & Average \\
\hline NC + Challenge & 3.33 & 3.25 & 3.33 & 3.416 & 3 & 3.2652 \\
\hline SB + Challenge & 1.66 & 1.5 & 1.41 & 1.16 & 1.16 & 1.378 \\
\hline MCFA + Challenge & 1.66 & 1.41 & 1.25 & 1.08 & 1.08 & 1.296 \\
\hline SB+ MCFA + Challenge & 0.833 & 0.833 & 0.583 & 0.66 & 0.75 & 0.7318 \\
\hline
\end{tabular}

Table 5: Average histopathology scoring of intestines, out of 4 .

Table 5, indicates histopathological score: higher pathological score of 3.2652 in group negative control and challenge, 1.378 was pathological score for group SB + challenge, 1.296 was the score for MCFA + challenge and lowest score of 0.7318 was noticed in combi- 
nation of SB + MCFA. The graphical representation of the same has been given in graph 2 . Their pictorial representation has been given in plate 2 and in image A,B, C and image D. This is an indication of better bactericidal effects of SB and MCFA against Clostridium perfringens.

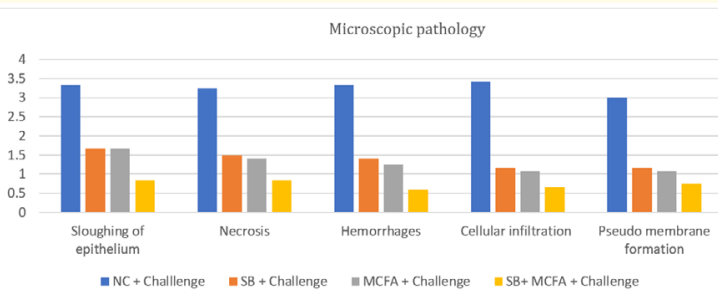

Graph 2: Average histopathology scoring of intestines, out of 4.

\begin{tabular}{|l|c|c|c|c|c|}
\hline & NC & $\begin{array}{c}\text { NC + } \\
\text { Challenge }\end{array}$ & $\begin{array}{c}\text { SB + } \\
\text { Challenge }\end{array}$ & $\begin{array}{c}\text { MCFA + } \\
\text { Challenge }\end{array}$ & $\begin{array}{c}\text { MCFA + SB + } \\
\text { Challenge }\end{array}$ \\
\hline First week & 0.7 & 0.71 & 0.42 & 0.41 & 0.21 \\
\hline Second week & 0.6 & 0.69 & 0.31 & 0.34 & 0.19 \\
\hline Third week & 0.5 & 0.74 & 0.25 & 0.27 & 0.17 \\
\hline Fourth week & 1.2 & 345 & 52 & 56 & 11 \\
\hline Fifth week & 0.6 & 359 & 35 & 33 & 13 \\
\hline Sixth week & 0.7 & 375 & 30 & 32 & 14 \\
\hline
\end{tabular}

Table 6: Clostridium from fecal CFU X $10^{3}$ /gram of fecal material.

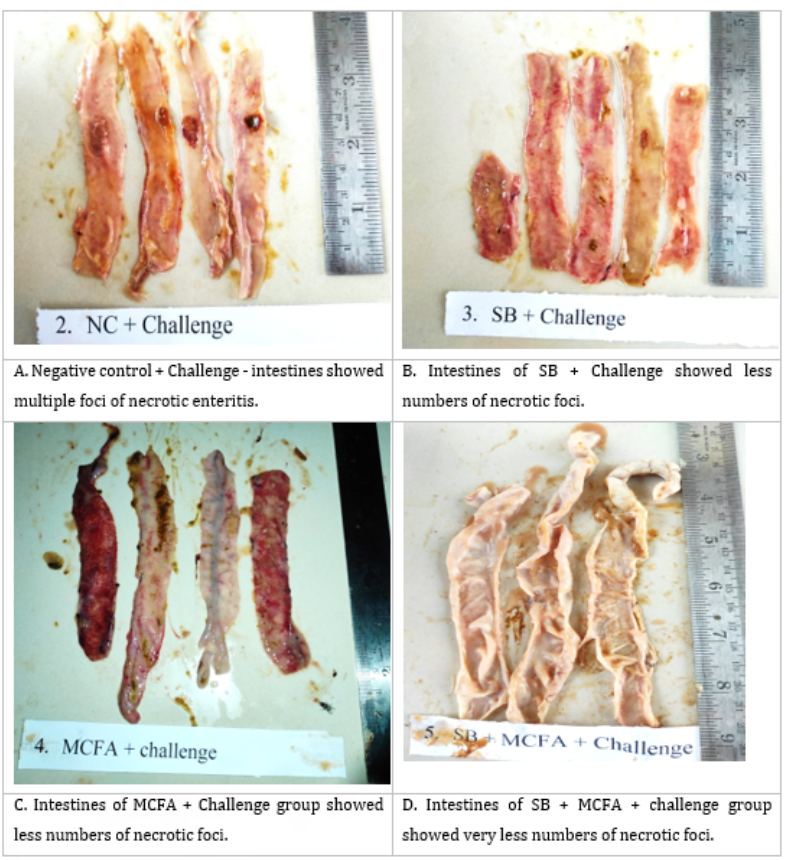

Plate 1

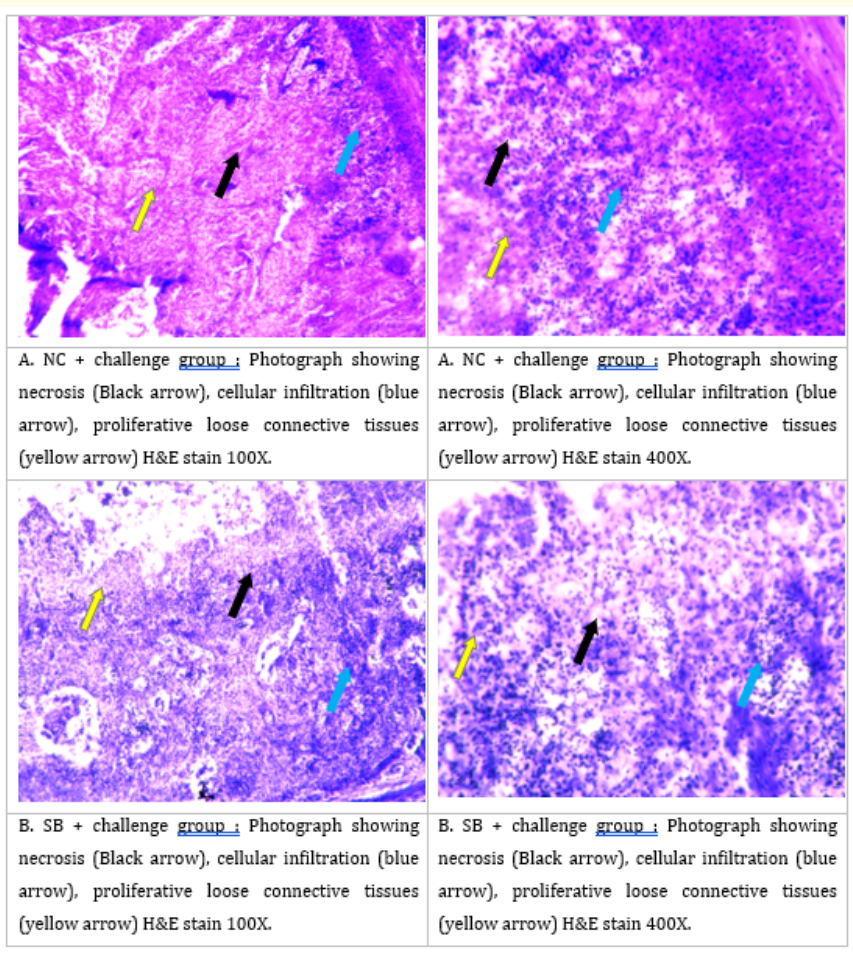

Plate 2

\section{Conclusions}

It is concluded that instead of using single molecules like sodium salts of butyrate or sodium salts of medium chain fatty acids, combined use of sodium salts of butyrate (SB) and medium chain fatty acids (MCFA) are able to combat bacterial infections in broiler chickens by reducing bacterial pathogens by greater extents. Both of these molecules are recommended for the better intestinal health of poultry and would be better alternative for the routine antibiotics.

\section{Bibliography}

1. Ranil Jayawardena., et al. "A review Enhancing immunity in viral infections, with special emphasis on COVID-19". Diabetes and Metabolic Syndrome 14.4 (2020): 367-382.

2. B Baltić., et al. "Importance of medium chain fatty acids in animal nutrition". IOP Conf. Series: Earth and Environmental Science 85 (2017): 012048.

3. Dolan Das., et al. "Presence of antibiotic residue and residual effect of tylosin tartrate in broiler". International Journal of Natural and Social Sciences 7.2 (2020): 29-35.

4. Baltić Ž M., et al. "Nutrition and meat quality". Tehnologija mesa 52 (2011): 154-159.

5. Randall S., et al. "Potential Impacts of Antibiotic Use in Poultry Production". Avian Diseases 50:161-172, 2006 
6. Agila Dauksiene., et al. "Comparison study of caecum microbial profiles, productivity and production quality of broiler chicken fed supplements based on medium chain fatty and organic acids". Multidisciplinary Digital Publishing Institute (2021).

7. Christian Cordts. Medium chain functional lipids: An underestimated ingredient. Published in Poultry world, Dec. (2020).

8. U AHSAN., et al. "Sodium butyrate in chicken nutrition: the dynamics of performance, gut microbiota, gut morphology, and immunity". World's Poultry Science Association 2016 World's Poultry Science Journal, June 2016 Received for publication September 29. 72 (2015): 265-275.

9. Elizabeth M Brunt. "Grading and Staging the Histopathological Lesions of Chronic Hepatitis: The Knodell Histology Activity Index and Beyond". Elizabeth M. Brunt, M.D., Surgical Pathology, 4th Floor, FDT, Saint Louis University Hospital, 3635 Vista Avenue, St. Louis, Hepatology Journal (2000): 241-246.

10. Deschepper K., et al. "A balanced mixture of medium chain fatty acids improves zootechnical performances and slaughter results of broilers". In Proceedings of the 19th European Symposium of Nutrition PPV 10 (2013).

\section{Volume 3 Issue 12 December 2021}

(C) All rights are reserved by Dayaram Suryawanshi., et al. 